\title{
Traceability to ensure food safety and consumer protection as typified by case studies of three meat processing plants
}

\author{
M. Stanisławek ${ }^{1}$, D. Miarka ${ }^{1}$, H. Kowalska² \& J. Kowalska ${ }^{1 \#}$ \\ ${ }^{1}$ Department of Technology and Food Evaluation \\ ${ }^{2}$ Department of Food Engineering and Process Management \\ ${ }^{1,2}$ Warsaw University of Life Sciences, Institute of Food Sciences, $159 \mathrm{c}$ Nowoursynowska St., \\ 02-776 Warsaw, Poland
}

(Submitted 11 October 2020; Accepted 26 February 2021; Published 1 April 2021)

\author{
Copyright resides with the authors in terms of the Creative Commons Attribution 4.0 South African Licence. \\ See: http://creativecommons.org/licenses/by/4.0/za \\ Condition of use: The user may copy, distribute, transmit and adapt the work, but must recognize the authors and the South African \\ Journal of Animal Science.
}

\begin{abstract}
Ensuring food safety is a legal obligation of the manufacturer or of the entity that places the product on sale. Traceability is one of the tools that are used to ensure food safety. It allows the withdrawal of a dangerous or non-compliant product from the market and determines the source of a threat. The aim of the study was to compare the functioning and effectiveness of traceability systems in selected approved meat industry plants. The system functioning in a large meat processing plant, in which the circulation of documents was implemented in a computer system, was compared with two smaller ones, in which paper documentation was carried out, but supported by a computer system. In these plants, the traceability system was based on internal procedures. Properly developed traceability procedures and simulations support and enable response in a crisis. Computer systems streamline and facilitate the traceability process. However, the comparative analysis showed that the use of paper records allowed for efficient identification of the source of the threat. The possibility of performing product traceability was confirmed in these plants. Internal markings and codes and documentation flow, staff training, and awareness proved helpful.
\end{abstract}

Keywords: consumer safety, food tracking, identification, meat products

\#Correspondence address: jolanta_kowalska@sggw.edu.pl

\section{Introduction}

Bovine spongiform encephalopathy (BSE), foot-and-mouth disease, dioxins in poultry meat, eggs and feed contaminated with E. coli (EHEC), and avian and swine flu have caused major crises in the food industry (Forås et al., 2015; Bai et al., 2017; Obal et al., 2017; Yu et al., 2018; Zhang et al., 2020). There have also been problems with falsification of ingredients in meat products (Cawthorn et al., 2013; Tembe et al., 2018). With these crises, information about the origins of food became more important for consumers (Thesmar \& Stevens, 2019; Soman et al., 2020; Zhang et al., 2020). Thus, protection of consumer health by ensuring the safety of food products is one of the most important aspects of modern food sector production (Czarniecka-Skubina \& Nowak, 2012; Gębski \& Kosicka-Gębska, 2014). In addition, incidents of contaminated food cause a loss in consumer confidence and expose entrepreneurs to financial losses (Southall, 2019).

More and more attention is paid to controlling food and introducing methods and systems that enable surveillance in production units. Food companies must have effective tools for identifying suppliers of foodstuffs, feed, farm animals and other substances intended to be added to food (European Commission, 2002; International Trade Centre, 2015; Furdik et al., 2015).One such tool is a traceability system (SouzaMonteiro \& Hooker, 2013; Bako et al., 2019). Such a system provides the ability to trace the product path forwards and backwards to determine the cause of non-compliance, guarantee the safety of food delivered to the customer, and minimize losses on the producer's side (Forås et al., 2015; Obal et al., 2017). The basic element of the traceability system is accurate documentation, which translates into economic benefits and consumer confidence. However, traceability throughout the supply chain can only be achieved if food movement records are kept in a way that matches the movement of products, combined with product 
identification (Kennedy \& McEntire, 2019). An effective system also ensures the efficient withdrawal of the product, and the implementation of corrective measures to prevent the reoccurrence of a threat or noncompliance (Obal et al., 2017; Dasaklis et al., 2019; Guzewich \& Miller, 2019). It is the responsibility of the manufacturer to simulate the traceability test and a product recall to ensure that personnel are trained and prepared for an emergency. In addition, it is a test of documentation and markings, which can be part of internal verification and improvement.

The purpose of the work was to compare the functioning of traceability systems by analysing the possibilities of efficient identification of raw materials, spices and additives in three approved meat industry plants with different slaughtering and production capacities.

\section{Materials and Methods}

Plant I has a certificate of compliance with ISO 9001 standard, and International Food Standard (IFS) and British Retail Consortium (BRC) certificates. The principles of the Hazard Analysis and Critical Control Points System (HACCP) are implemented. Plant I is a large company that employs approximately 1500 employees. The traceability requirement is carried out with a computer system supported by paper documentation. The traceability system is based on the requirements of ISO 9001 and IFS and BRC standards and is verified during internal and external (certification) audits.

Plants II and III have also implemented the HACCP principles as required legally. HACCP is not certified. Internal documentation was prepared in all plants. Traceability was performed in accordance with internal procedures. Plants II and III meet the legal requirements and verify the effectiveness of the procedure through internal audits. All plant employees are trained in accordance with internal training schedules, which cover the principles of good hygiene and production practice, HACCP, workplace instructions, traceability and other internal requirements. Training is carried out by the company's employees or external units. All training is verified. In Plant II, the traceability system is carried out with paper documentation and is partly computer aided. In Plant III, the traceability system is implemented only through paper documentation.

These plants provide case studies of traceability systems. These systems were assessed by analysis of internal documentation. This documentation consisted of registers of acceptance of raw material, spices, additives, identification and traceability procedures, meat cutting cards, production records, thermal processing cards, goods transfer and packaging cards, and product withdrawal procedures. Terms, definitions and abbreviations that are commonly used in traceability systems are given in Table 1.

Table 1 Definitions of terms and abbreviations used herein in the assessment of traceability systems

\begin{tabular}{|c|c|c|}
\hline \multicolumn{2}{|c|}{ Terms and abbreviations } & Description \\
\hline Index (product code) & $\begin{array}{l}\text { Individua } \\
\text { additives }\end{array}$ & $\begin{array}{l}\text { it number identifying each raw material, semi- and finished product, spices, } \\
\text { aging and auxiliary materials used in the production process }\end{array}$ \\
\hline Party & $\begin{array}{l}\text { A 10-dig } \\
\text { delivery }\end{array}$ & $\begin{array}{l}\text { Der that is automatically generated by the computer system when accepting a } \\
\text { ssigned by a designated employee }\end{array}$ \\
\hline Farm code & $\begin{array}{l}\text { The inte } \\
\text { system }\end{array}$ & entification number of the holding, used when registering data in the computer \\
\hline $\begin{array}{l}\text { Headquarters herd } \\
\text { number }\end{array}$ & $\begin{array}{l}\text { The num } \\
\text { and Moc }\end{array}$ & $\begin{array}{l}\text { signed to each producer of agricultural products by the Agency for Restructuring } \\
\text { tion of Agriculture, forwarded to veterinary inspection for information }\end{array}$ \\
\hline Production batch & $\begin{array}{l}\text { 12-digit } \\
\text { D day of }\end{array}$ & $\begin{array}{l}\text { with the structure TTDXXXXXXXXXX where TT means the next week of the year, } \\
\text { eek, } X X X X X X X X \text { index number }\end{array}$ \\
\hline BB & $\begin{array}{l}\text { Best bef } \\
\text { the stora }\end{array}$ & $\begin{array}{l}\text { te: the period during which the product remains safe and maintains quality under } \\
\text { nditions specified on the label }\end{array}$ \\
\hline HDI & Commer & entification document \\
\hline \multicolumn{3}{|c|}{ Marking of the cutting part } \\
\hline \multicolumn{2}{|c|}{$\begin{array}{l}\text { TTDX + partition line number } \\
\text { or } \\
\text { TTDX + inventory index number } \\
\text { Food systems and standards }\end{array}$} & $\begin{array}{l}\text { TT: next week number } \\
\text { D: day of the week } \\
\text { X: additional internal identification in the plant }\end{array}$ \\
\hline \multicolumn{2}{|l|}{ HACCP } & Hazard Analysis and Critical Control Points System \\
\hline \multicolumn{2}{|l|}{ IFS } & International Food Standard \\
\hline \multicolumn{2}{|l|}{ BRC } & British Retail Consortium \\
\hline
\end{tabular}




\section{Results}

The operations of Plant I consist of slaughtering pigs, cutting up half-carcases and processing the meat. After cutting, the culinary items intended for sale are packed in vacuum packaging or in a modified atmosphere. The weekly cutting size is 140 tons. The weekly volume of meat processing is about 120 tons. Plant I produces smoked meats, sausages and offal products. Full identification of the technological process, including raw materials, spices and additives, is documented with computer systems. The amounts of materials are recorded at individual stages, starting with accepting animals for slaughter, passing halfcarcasses for chilling and cutting, and then processing, including auxiliary stages, up to delivering the product for dispatch (Table 2).

Table 2 Registration of information pertaining to production stages in the computer system

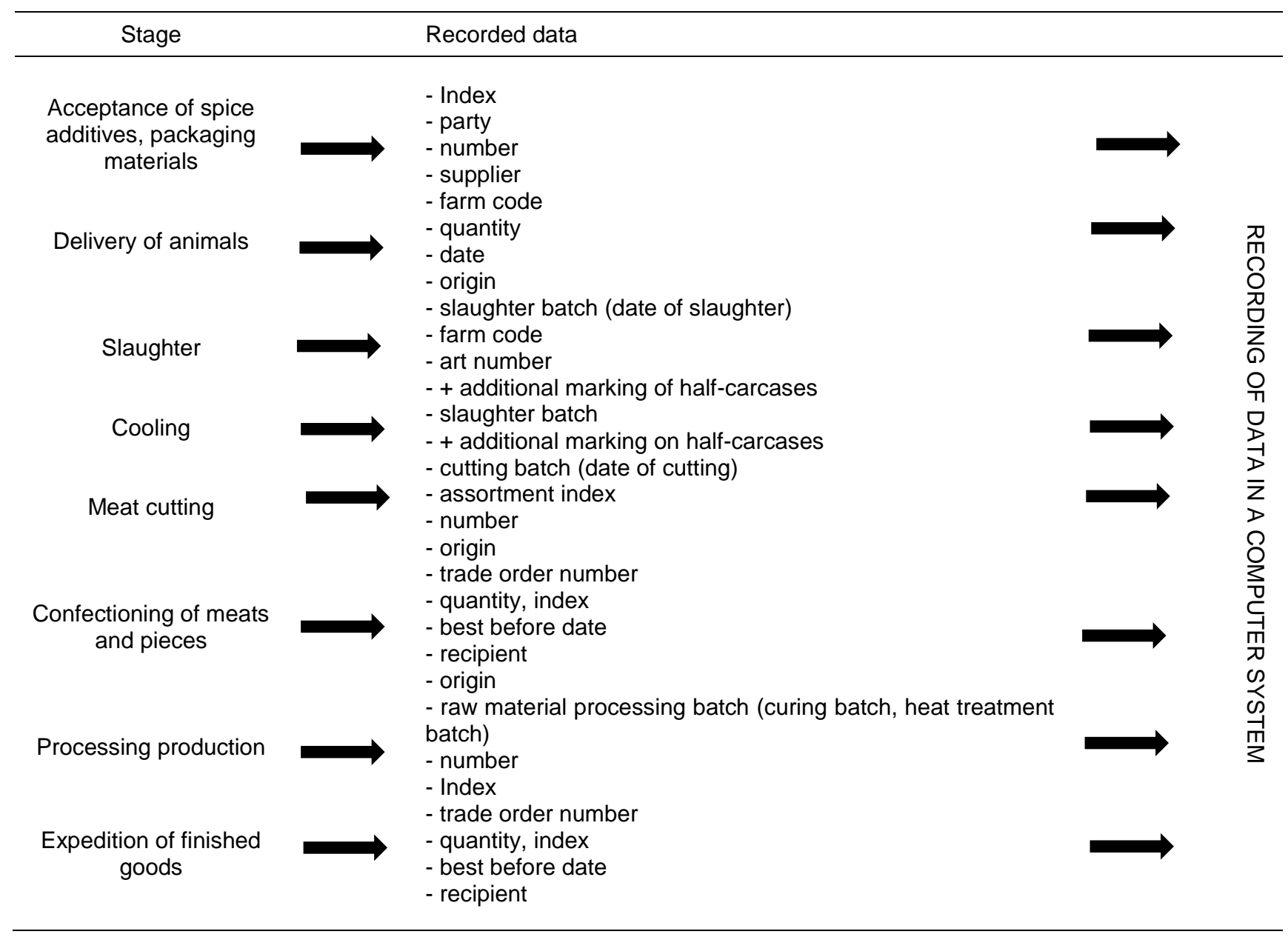

Pigs admitted to the establishment must be accompanied by a health certificate and information about the food chain. Each unit is identified by an ear tag or tattoo. When a live animal is purchased from a delivery agent, it is accompanied by a specification that enables the origin of the individual animal to be identified (Table 3). 
Table 3 Data provided on acceptance of live animals into the slaughter plant

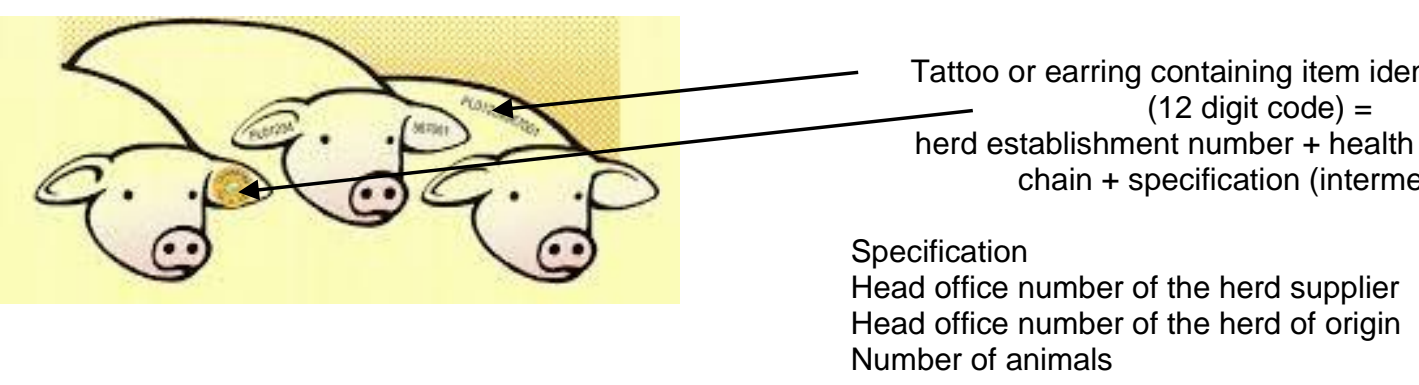

Carcases are marked with the slaughter batch number, consecutive slaughter numbers, and the class of muscle in accordance with the SEUROP system (System of Classification and Evaluation of Carcases after Slaughter), then transferred for chilling and cutting. Data on the origin of carcases are entered into the computerized system. The slaughter batch, which is the day of slaughter, is a 12-digit code, which is transmitted automatically during the subsequent stages of production. The cutting batch is marked on the day of cutting, which is also the production batch. All containers, trolleys, pools of raw material, stuffing, semi-finished and finished products are marked with labels. Identification of the meat is also entered into the system. As the meat is transferred from cutting to further processing stages, for example curing or stuffing, appropriate codes are given to document the process.

Many spices and additives are used in the production of meat products and fresh chilled elements (Table 4). The system generates their batch number automatically, which accompanies these ingredients through the production process. The batch number of packaging materials is the date of their release from the warehouse to a specific department of the plant.

Table 4 Identification of batches of spices, additives and packaging materials accepted into the plant

Stage of acceptance of batch of spices, additives and packaging materials

\section{0}

This number identifies

- delivery date

- supplier

- quantity delivered

- shelf life

The plant identifies the processed products with the accuracy of the production batch, whose number (assortment code and batch number) is given when the semi-finished products are filled or suspended on a heat treatment trolley. This marking does not change through subsequent production stages (cooling down, storage). The number entered into the computer system is linked to the order number, which is a 10-digit code generated by the system that is visible on the label of the finished product and includes the weight and the packaging batch number. Additionally, the correctness of data on labels is checked during packaging. The production batch number, assortment code, quantity, expiry date assigned to the batch, and the recipient are coded In the order number (batch), which is placed on the final label. After completing the order, employees scan barcodes of finished products, and data from labels are automatically transferred to the IT system. After the codes of all packages are scanned, a collective label is applied on the pallet, after which the goods are shipped or transferred to the finished product warehouse. Collective labels on pallets are also verified in a random manner.

Plant II cuts and processes about 2.5 tons of pork and $400-600 \mathrm{~kg}$ of beef cutting per week. At the plant, traceability is carried out in paper form, with little support from a computer system. The receipt of pork 
halves and beef quarters is accompanied by an HDI (commercial identification document) containing information about the origin of the raw material and a label (European Commission, 2000; 2011; 2013). Accepted beef quarters must bear an identification number for each item. Acceptance is recorded on the purchase forms. At each stage, from the receipt of half-carcases or quarters of pork or beef to the finished product, the goods must be labelled with an internal code as defined in the factory procedures. After the meat has been cut and reclassified, all meat containers and meat tanks are labelled with codes. Fresh (cooled) pig meat and beef elements for sale are labelled with the data required by law (European Commission, 2000). These data include the name of the raw product, its origin, the approval number for the slaughterhouse in which the animal was slaughtered, identification of the European Commission member state where the slaughterhouse and processing plant were located, the code which connects the product to the animal(s) from which it originated, a lot number for the product, any consumer advisories including a best before date and storage conditions, contact details of the manufacturer, and the net weight of the product.

The meat is coded with internal numbers that are transmitted between the stages of the production process. The label on the product in the finished product store indicates its name and the production date, which is also the batch number. The person who packages the product for sale places a label on the container, which bears the name of the product, the list of ingredients (allergenic ingredients are distinguished), net weight, storage conditions, expiry date, according to the storage trials for that product, the name and address of the producer, and the veterinary mark. Spices and additives accepted into the plant are recorded in the documentation using the batch number assigned by the plant each time of delivery. Paper records are kept with accuracy to the production batch, that is, the quantity of a given assortment produced on a given day.

Plant III is comparable with Plant II in production volume and employment. It slaughters, cuts, and processes pork. About 20 pigs are slaughtered each week. In addition, the plant also buys meat in elements that are given batch numbers in the documentation. Approximately 2.5 tons of pork cuts are produced with a total production volume of about 4 tons. In Plant III, identification at individual stages is carried out by designated employees, who make entries in the paper documentation. The raw materials have labels that contain internal numbers assigned according to the rules described in the procedure. These labels accompany the product at all stages until the final label is placed on it. Each animal to be slaughtered has its own registration number in the form of an ear tag or tattoo. The receipt of each batch of animals is accompanied by required documentation including the date, origin of the animals (farm), a health certificate, and a specification stating the numbers of the holdings with the addresses and registration numbers of the animals for purchases from an intermediary. Acceptance of the pigs is recorded in the internal documentation. After slaughter, each piece is marked with a sequential number. Each delivery is marked with labels, and HDIs are delivered each time.

After cutting and classification, each container receives a label that enables the origin of the meat to be identified. Spices and additives must be recorded in the paperwork using the batch number assigned at the time of acceptance. The records kept at successive stages of production (curing, mixing, heat treatment, storage) make it possible to link the date of production of the product with its batch number and the origins of raw material, spices and additives. Finished products sent for distribution are marked with a coded batch number and labelled in accordance with EC Regulation 1169/2011 (European Commission, 2011).

Plants I and II keep records of their sales in electronic form, which makes it possible to identify customers better if a non-compliant product is found. In addition, the packaging of finished products is labelled with the batch number. When the finished products are sold without packaging, labels that identify each assortment are placed on the containers. Although the only system that is implemented in Plants II and III is HACCP, it is based on the traceability system in both companies.

Only Plant I carries out simulation of traceability, which is performed for each product group once a year in both directions, that is, from raw material, additives and spices to the finished product and back, which results from the plant's BRC and IFS systems (Górna, 2016). Plant I analyses the correctness of all documents and the effectiveness of employee training. The employee communicates the risk to the supervisor. A crisis team is convened to conduct a preliminary risk analysis. Afterwards, individual people are commissioned to establish distribution lists and the size of the disputed batch. All information and forms for the entire process of the batch in question are collected and filled in. The preliminary analysis provides the basis for the product safety coordinator to stop the distribution of product to large customers. The traceability simulation is complete with stopping the shipment of the batch and preparing the message to the recipients or media at central level. However, the analysis of traceability systems in plants II and III showed that an internal system without a high degree of technological sophistication can provide a means of protecting integrity of the product and indirectly the consumer. All plants confirmed awareness of and care for product safety. Product safety can be increased by training, raising awareness, verification, and employee vigilance and cooperation with suppliers. In the past year, Plant I stopped one batch of finished product because it 
contained foreign body fragments. Plant II introduced recall procedures and plant III withdrew finished products because of their failure to meet microbiological requirements.

\section{Discussion}

Traceability is at the heart of ensuring food safety (Kennedy et al., 2020). Entry batch information, documents, specifications, and the types of finished product are the most important elements in traceability. In the United States, the Food Safety and Inspection Service (FSIS) also requires companies to keep records of daily production, production batches, packaging and labelling to facilitate product traceability. The labels of each product must include the number assigned by FSIS to each plant (Stevens, 2019). Data on product types and intended use are crucial in the recall of non-compliant products. Slaughter lots and finished products are used to facilitate the traceability system. When a product is packed, the IT system retrieves information about the batch from the system. One of the main elements of the traceability system and of ensuring food safety is proper labelling (Soman et al., 2020). Codes on the packaging labels enable the path of product data to be followed (Yu et al., 2018). However, the label is intended primarily for consumers. It should fully specify the composition of the product (Frans, 2017). In addition, Ellies-Oury et al. (2019) showed that consumers would be interested in labelling a meat grading system based on tenderness and that this information could increase beef consumption.

By saving information about the product, raw materials and auxiliary materials, production parameters, storage of finished product samples and recipients, it is possible to run a traceability system that monitors the quality and safety of products and thus increases consumer confidence in production plants and the food they produce (Fan et al., 2020). A food safety assurance system with traceability and recall procedures is the basis of a food defence plan to counteract the risks (Bogadi et al., 2016). The small number of notifications issued by the Rapid Alert System for Food and Feed, which have resulted in the recall of meat and meat products in recent years demonstrates that in the European Union the food that is produced is safe for the consumer.

The basis of the traceability system is the batch number, from which it is possible to identify the meat raw material, spices and additives used in finished products. A traceability system that registers cattle producers makes it possible to control the movement of cattle, and can form the basis for registration and identification of animals in accordance with legal regulations (European Commission, 2011; 2013). In Uruguay, two ear tags are used to identify animals, one of which is marked visually and the other has an electronic RFID (radio frequency identification) (Abraham et al., 2014). The animals are pooled in batches and given a herd number, which indicates the origin, quantity and ownership of the animals. Records of the stages of the production process are kept in the plant, enabling the identification of all the ingredients from the moment the meat raw materials, spices and additives are received. Finished products sent for distribution are labelled in accordance with legal regulations (European Commission, 2011). The traceability system prevents fraud by ensuring the exact identification of products and their batch (Violino et al., 2019).

The use of an electronic meat traceability system in slaughterhouses and processing plants has significantly improved the process of internal verification, and the process of supervision, including the elimination of risks and possible product withdrawal from the market. Traceability in the food chain combines internal and external traceability systems. Internal traceability covers all materials used in production, manufactured products and recipient register. In contrast, external traceability concerns the movement of products into and out of the company along with product data. This enables the product to be traced back and forth in problems (Kennedy \& McEntire, 2019).

Automated product identification is becoming more important. Internal traceability systems often use barcodes, two-dimensional codes and RFID (Fan et. al., 2020). In meat products, various technologies for electronic identification and DNA barcodes are used (Daoud \& Trigui, 2019). The unquestionable advantage of using RFID technology is the speed of reading and full automation (Violino et al., 2019). This technology protects and encrypts product information that cannot be changed once saved in the manufacturing process flowchart, and with the use of blockchain technology facilitates the traceability of the product through the supply chain (Fan et al., 2020). Radio frequency identification devices label each element electronically to ensure highly accurate traceability in the livestock industry. In the traceability system, animals sent for slaughter are linked to their product. The use of barcodes is also popular for food traceability, and scanning them reduces errors (Kirkness, 2019). In the meat industry, barcodes usually contain information about weight, batch number, date of manufacture and best before date. In the plant, all these guidelines are taken into account and implemented flawlessly. Many authors encourage the use of computer systems that facilitate the recording of information and analysis. Crčić et al. (2020) proposed double marking with infrared printing technology. Thakur et al. (2020) tested dot peening and laser engraving connected to the RFID system, whereas Zhao et al. (2018) proposed DNA fingerprinting and radio frequency identification that would follow the animals and their meat through processing to the point of consumption. Regardless of the 
identification system, all authors emphasized the important role of traceability, and the need for thorough analysis and documentation of all processing steps.

In the detection of discrepancies, first of all data records are analysed regarding the raw materials, additives and auxiliary materials, parameters in the technological cycle and its course (correctness), and employees that supervised the process. It is also possible to indicate a human error, for example in inappropriate packaging or intentional action. When an irregularity is detected, a robust traceability system makes it possible to identify the non-compliant or dangerous product and withdraw it from the market as required by the legal system. Each company must then stop non-compliant products, withdraw them, and inform the authorities and recipients (Górna, 2016). An effective and verified traceability system allows the plant to react immediately and communicate with all links in the supply chain and customers (Obal et al., 2017). A positive effect of this system is an increase in the level of safety of customers and minimization of financial losses of the company (Czarniecka-Skubina \& Nowak, 2012).

The traceability system, as an element of food safety, focuses on increasing access to information about contaminated food and its withdrawal from the market (Kennedy \& McEntire, 2019). It also helps to prevent the distribution of contaminated food and protects the health of consumers. Traceability includes backward tracing (analysis of technological process steps and all participants) and forward tracing (identification of all recipients of a hazardous or contaminated product and recall of the product) (McEntire, 2019). Withdrawal procedures are available to all the companies concerned in their records. If a manufactured foodstuff does not meet the requirements of safe food, the establishment must take immediate action to withdraw it from the market. The situation must be immediately brought to the attention of the official control authorities. Based on the plant's traceability procedure, the operator should determine the production date, size and batch number. In the back-tracing procedure, the manufacturer and regulators are required to search records at every stage of the production chain. Distribution lists are then established and recipients are notified of the need to stop sales. The next step is to withdraw the product from the market. The withdrawn product is sent to separate warehouses or sent directly to disposal, accompanied by a commercial document for animal by-products of the relevant category. The product name, batch number and size, list of consignees, reasons for withdrawal and duration of the withdrawal procedure must be recorded. Weaver et al. (2017) analysed the effects of a product recall and observed that the company's share prices had fallen and three groups of costs had been incurred by producers, namely disposal of the non-conforming product, business interruption, and customer reimbursement. A robust traceability system and its effectiveness can reduce these costs.

Amuno et al. (2018) evaluated the feasibility of using IT systems for traceability in small and mediumsized beef processing companies. They found that implementing IT systems in most small businesses had a negative impact. Entrepreneurs believed that IT systems burdened employees, required greater responsibility, and increased the probability of errors. However, the authors concluded that simple IT systems could reduce risk in these enterprises through better implementation of traceability. Yan et al. (2018) developed a traceability design based on the HACCP principles and established critical points. They pointed to the need to identify participants in the process request them to collect relevant information to facilitate traceability. The basis of the proposed concept was the development of the flow chain from Chinese farmers through production and distribution of meat to the consumer. The verification of the concept showed that the model made it possible to identify problematic processes and obtain data necessary for the traceability system, and thus to ensure the safety of sheep meat.

Obal et al. (2017) hypothesized that for the traceability system to be effective, they must be verified through simulation and recall training. Food industry plants run a recall simulation that is usually limited to the raw materials used in production or the finished goods. Companies rarely perform recall simulations with their suppliers or customers, as testing the entire chain is much more difficult (Kennedy \& McEntire, 2019). Most manufacturers carry out recall simulations much more often than they actually withdraw the product, allowing them to test the accuracy of their records and the speed of response to a threat (Kirkness, 2019).

\section{Conclusion}

Every food producer is responsible for the safety of the food produced and offered. Plants implement mandatory HACCP systems and have voluntary standards that support process supervision. Each plant used in this case study has defined an internal traceability system to identify the elements and participants of the process. The analyses showed the feasibility of implementation of appropriate rules, regardless of the size of the plant and the degree of computerization. In all units, the traceability system made it possible to quickly identify and locate the production batch in question and withdraw products that posed a threat to human life and health. The essence of traceability is to adapt procedures and guidelines to the unit's internal capabilities and needs, and to prepare personnel through training. Conducting traceability at the plant allows 
confirmation of the absence of risk and prompts analysis of the next stages of the food chain. For consumers it is information that the plant supervises from the whole production chain and uses protect their health.

\section{Acknowledgements}

This research did not receive any specific grant from funding agencies in the public, commercial or not-for-profit sectors. Publication of the article was financed from the co-authors' own funds

\section{Authors' Contributions}

The authors contributed equally to this article.

\section{Conflict of Interest Declaration}

The authors declare that they have no conflicts of interest with regard to the work.

\section{References}

Abraham, D., Dassatti, G. \& Cal, A., 2014. Traceability: An electronic information system for the meat industry. Health Technol. 4, 171-176. https://doi.org/10.1007/s12553-014-0081-z

Amuno, M., Turner, P. \& Sadegh, T.M., 2018. Mitigating traceability risks amongst SMEs along the beef supply chain: A multiple case study approach to investigating the role and potential impact of Information technology. ACIS 2018 Proceedings, 49. https://aisel.aisnet.org/acis2018/49

Bai, H., Zhou, G., Hu, Y., Sun, A.., Xu, X., Liu, X. \& Lu, Ch., 2017. Traceability technologies for farm animals and their products in China. Food Control 79, 35-43. https://doi.org/10.1016/j.foodcont.2017.02.040

Bako, H.K., Dandago, M.A. \& Nassarawa, S.S., 2019. Food traceability system: Current state and future needs of the Nigerian poultry and poultry product supply chain. Chem. Biomol. Eng. 4(3), 40-44. DOI: 10.11648/j.cbe.20190403.11

Bogadi, N.P., Bonović, M. \& Babić, I., 2016. Food defence system in food industry: Perspective of the EU countries. J. Verbrauch. Lebensm. 11, 217-226. https://doi.org/10.1007/s00003-016-1022-8

Crčić, D., Žiljak Gršić, J. \& Jurečić, D., 2020. Infrared printing technique for the security marking of traceability certificates for meat products. Tech. J. 14, 2(2020), 100-103. https://doi.org/10.31803/tg-20200313160147

Cawthorn, D.-M. Steinman, H.A. \& Hoffman, L.C., 2013. A high incidence of species substitution and mislabelling detected in meat products sold in South Africa. Food Control 32(2), 440-449. https://doi.org/10.1016/j.foodcont.2013.01.008

Czarniecka-Skubina, E. \& Nowak, D., 2012. System for tracking and tracing flow and origin of food as tool to ensure consumer safety. Food Science Technology Quality 5(84), 20-36.

Daoud, M.K. \& Trigui, I.T., 2019. Smart packaging: Consumer's perception and diagnostic of traceability information. Proc. 4th International Conference on Digital Economy, Beirut, Lebanon, 15-18 April 2019. Springer Nature Switzerland AG, Cham, Switzerland. Pp. 352-370. https://doi.org/10.1007/978-3-030-30874-2_28

Dasaklis, T.K., Casino, F., Patsakis, C. \& Douligeris, C., 2019. A framework for supply chain traceability based on blockchain tokens. Proc. International Conference Business Process Management, Vienna, Austria, 1-6 September 2019, Springer Nature Switzerland AG, Cham, Switzerland. Pp. 704-716. https://doi.org/10.1007/978-3-030-37453-2_56

Ellies-Oury, M.P., Lee, A., Jacob, H. \& Hocquette, J.F., 2019. Meat consumption - What French consumers feel about the quality of beef? Italian J. Anim. Sci. 18,1, 646-656. https://doi.org/10.1080/1828051X.2018.1551072

European Commission, 2000 Regulation (EC) No 1760/2000 of the European Parliament and of the Council of 17 July 2000 Council Regulation (EC) No 820/97. https://ec.europa.eu/transparency/regdoc/index.cfm?fuseaction $=$ fmb\&language $=e n$

European Commission, 2002 Regulation (EC) No 178/2002 of the European Parliament and of Council of 28 Januar 2002 laying down the general principles and requirements of food law, establishing the European Food Safety Authority and laying down procedures in matters of food safety. https://ec.europa.eu/transparency/regdoc/index.cfm?fuseaction=fmb\&language $=$ en

European Commission, 2011 Regulation (EU) No 1169/2011 of the European Parliament and of the Council of 25 October 2011 on the provision of food information to consumers. https://ec.europa.eu/transparency/regdoc/index.cfm?fuseaction=fmb\&language $=$ en

European Commission, 2013 (UE) No 1337/2013 of 13 December 2013 laying down rules for the application of Regulation (EU) No 1169/2011 of the European Parliament and of the Council (OJ L 335/19, 14.12.2013). https://ec.europa.eu/transparency/regdoc/index.cfm?fuseaction $=$ fmb\&language $=e n$

Fan, Z.P., Wu, X.Y. \& Cao, B.B., 2020. Considering the traceability awareness of consumers: Should the supply chain adopt the blockchain technology? Ann. Oper. Res. 1-24. https://doi.org/10.1007/s10479-020-03729-y

Forås, E., Thakur, M., Solem, K. \& Svarva, R., 2015. State of traceability in the Norwegian food sectors. Food Control 57, 65-69. https://doi.org/10.1016/j.foodcont.2015.03.027

Frans, H., 2017. Labelling of food: A challenge for many. Veterinarski Glasnik. 71 (1),16-23. https://doi.org/10.2298/VETGL170214001H

Furdik, K., Pramudianto, F., Ahlsén, M., Rosengren, P., Kool, P., Zhenyu, S., Brizzi, P., Paralic, M. \& Schneider, A., 2015. Food traceability chain supported by the Ebbits loT middleware. Dynamics in Logistics 343-353. https://doi.org/10.1007/978-3-319-23512-7_33 
Gębski, J. \& Kosicka-Gębska, M., 2014. Analysis of a traceability process in selected meat processing plants in Poland. Logistics 6, 13299-13302.

Górna, J., 2016. Management of incidents and product withdrawal. Studia Oeconomica Posnaniensia 4(10), 83-93. DOI: 10.18559/SOEP.2016.10.6

Guzewich J. \& Miller B., 2019. Public Health. In: J. McEntire \& A. Kennedy (eds). Food traceability. Food Microbiology and Food Safety series. Springer Nature Switzerland AG, Cham, Switzerland. Pp. 27-49. https://doi.org/10.1007/978-3-030-10902-8_3

International Trade Centre, 2015. Traceability in food and agricultural products. Geneva, Switzerland. No 91/2015.

Kennedy, A.W. \& McEntire, J., 2019. Connecting the dots with whole chain traceability. In J. McEntire \& A. Kennedy (eds). Food traceability. Food Microbiology and Food Safety series. Springer Nature Switzerland AG, Cham, Switzerland. Pp. 181-192. https://doi.org/10.1007/978-3-030-10902-8_12

Kennedy, A., Stitzinger, J. \& Burke, T. 2020. Food traceability. In: A. Demirci, H. Feng \& K. Krishnamurthy (eds). Food safety engineering. Springer Nature Switzerland AG, Cham, Switzerland. Pp. $227-245$. https://doi.org/10.1007/978-3-030-42660-6_10

Kirkness, J., 2019. Tools and solutions - internal traceability. Food traceability. Food Microbiology and Food Safety series. Springer, Cham. Pp. 145-179. Doi: 10.1007/978-3-030-10902-8_11

McEntire, J., 2019. Introducing the drivers and complexities to tracing foods. In: J. McEntire \& A. Kennedy (eds). Food traceability. Food Microbiology and Food Safety series. Springer Nature Switzerland AG, Cham, Switzerland. Pp.1-12. https://doi.org/10.1007/978-3-030-10902-8 1

Obal, M., Lesiów, T. \& Śmiechowska, M., 2017. Traceability of raw meat in the selected trade company. Eng. Sci. Technol. 3(26), 28-58. DOI: 10.15611/nit.2017.3.02

Soman, M., Paul, R.J., Antony, M. \& Sasidharan, S.P., 2020. Detecting mislabelling in meat products using PCRFINS. J. Food Sci. Technol. 57, 4286-4292. https://doi.org/10.1007/s13197-020-04641-w

Southall, M., 2019. Industry benefits. In: J. McEntire \& A. Kennedy (eds). Food traceability. Food Microbiology and Food Safety series. Springer Nature Switzerland AG, Cham, Switzerland. Pp. 51-62. https://doi.org/10.1007/978-3-030-10902-8_4

Souza-Monteiro, D.M. \& Hooker, N.H., 2013. Food safety and traceability. In: W. Armbruster \& R. Knutson (eds). US programs affecting food and agricultural marketing. Natural Resource Management and Policy series. Springer, New York, NY. https://doi.org/10.1007/978-1-4614-4930-0_10

Stevens, S.K., 2019. Tracing the food safety laws and regulations governing traceability: A brief history of food safety and traceability regulation. In: J. McEntire \& A. Kennedy (eds). Food traceability. Food Microbiology and Food Safety series. Springer Nature Switzerland AG, Cham, Switzerland. Pp. 13-26. https://link.springer.com/chapter/10.1007/978-3-030-10902-8_2

Tembe, D., Mukaratirwa, S \& Zishiri, O.T., 2018. Undeclared meat species in processed meat products from retail franchises in the Durban Metropole, KwaZulu-Natal, South Africa, using species-specific DNA primers. Food Protection Trends 38(6), 440-449.

Thakur, M., Møen Tveita G., Vevleb, G. \& Yurtc T., 2020. A framework for traceability of hides for improved supply chain coordination. Comput. Electron. Agr. 174, 105478. https://doi.org/10.1016/j.compag.2020.105478

Thesmar, H.S. \& Stevens, S.K., 2019. Meat and poultry traceability - its history and continuing challenges. In: J. McEntire \& A. Kennedy (eds). Food traceability. Food Microbiology and Food Safety series. Springer Nature Switzerland AG, Cham, Switzerland. Pp. 71-80. https://doi.org/10.1007/978-3-030-10902-8_6

Violino, S., Antonucci, F., Pallottino, F., Cecchini, C., Figorilli, S. \& Costa, C., 2019. Food traceability: A term map analysis basic review. Eur. Food Res. Technol. 245, 2089-2099. https://doi.org/10.1007/s00217-019-03321-0

Weaver, T.L., Crandall, P.G., O'Bryan, C.A. \& Thomsen, M.R., 2017. A robust market withdrawal system can reduce your product recall costs. Food Protection Trends 37(3), 154-160. http://www.foodprotection.org/files/foodprotection-trends/may-jun-17-weaver.pdf

Yan, C., Huanhuan, F., Ablikim, B., Zheng, G., Xiaoshuan, Z. \& Jun, L., 2018. Traceability information modeling and system implementation in Chinese domestic sheep meat supply chains. J. Food Process Eng. 41(7), e12864. https://doi.org/10.1111/jppe.12864

Yu, X., Liu, P., Ren, W., Zhang, C., Wang, J. \& Zheng, Y. 2018. Safety traceability system of livestock and poultry industrial chain. In: Proc. 4th International Conference on Cloud Computing and Security (ICCCS), Haikou, China, 8-10 June 2018. Springer Nature Switzerland AG, Cham, Switzerland. Pp. 3- 12. https://doi.org/10.1007/978-3030-00021-9_1

Zhang, A., Mankad, A. \& Ariyawardana, A., 2020. Establishing confidence in food safety: Is traceability a solution in consumers' eyes? J. Consum. Prot. Food Safety 15, 99-107. https://doi.org/10.1007/s00003-020-01277-y

Zhao, J., Li, A., Jin, X. \& Pan L., 2020. Technologies in individual animal identification and meat products traceability. Biotechnol. Biotec. Equip. 34, 48-57. https://doi.org/10.1080/13102818.2019.1711185 